УДК 372.851

DOI: $10.17277 /$ voprosy.2015.03.pp.123-130

\title{
CASE TASKS AS A MEANS OF FORMATION OF STOCHASTIC COMPETENCE
}

\author{
A. D. Nakhman, I. Yu. Ivanova, T. V. Selyanskaya \\ Tambov State Technical University; Tambov Institute \\ for Advanced Studies of Educators, Tambov \\ Reviewed by Doctor of Physical and Mathematical Sciences, \\ Professor G. M. Kulikov
}

Keywords: case tasks; processing method of formation; stochastic competence.

\begin{abstract}
The structure and conditions of formation of stochastic competence of pupils are analyzed. The concept of case tasks as a component of the technological process of formation of stochastic competence is offered. An original series of case tasks is designed.
\end{abstract}

Introduction. The concept of stochastic competence is rather new. Its emergence is connected with two factors:

1) the formation in the domestic education system of competence-based approach;

2) more and more increasing public interest in probability theory, mathematical statistics, the theory of casual processes and application of probabilistic and statistical methods in the most various areas of science, equipment, production and economy.

We will use the term "stochastic competence" as the ability to mathematical and practical activities connected with mastering of combination theory, the main concepts and the facts of probability theory, mathematical statistics and the theory of casual processes. Stochastic competency in our understanding is readiness for such an activity, ability to mobilize knowledge in the field of stochastics for its use in new conditions, in doing practical, production and other tasks.

From our point of view it is impossible to draw an accurate distinction between stochastic competence and competency; in other words, these two

Нахман Александр Давидович - кандидат физико-математических наук, доцент кафедры «Прикладная математика и механика», e-mail: alextmb@mail.ru, ТамбГТУ; Иванова Ирина Юрьевна - доцент кафедры общеобразовательных дисциплин; Селянская Татьяна Владиславовна - кандидат филологических наук, доцент кафедры общеобразовательных дисциплин; ТОГОАУ ДПО «Тамбовский институт повышения квалификации работников образования», г. Тамбов. 
concepts, integrating in themselves numerous components (as it is noted further), can be considered as indistinct sets.

The general conditions for formation of the corresponding competence/ competency are the following [1]:

- knowledge of conceptual bases of stochastics;

- knowledge of various methods of the probabilistic and statistical analysis of the surrounding phenomena, probabilistic modeling and knowledge of statistical regularities of reality;

- use of methodology of modern science, understanding of deep internal unity of empirical and theoretical levels of acquisition of the random world.

In the structure of stochastic competence/competency we allocate the following main components.

1. Motivational and valuable: motivation, the interest in mathematical activity.

2. Cognitive: knowledge and abilities in the field of probability theory and mathematical statistics.

3. Operational: experience of practical application of mathematical knowledge, reinforcement of abilities at the level of skills.

4. Reflexive: inclusion in mathematical activity, reflection of mathematical activity (in particular, self-checking, introspection and self-assessment).

1. The stochastic line in the Federal State Educational Standards (FSES). According to the Concept of development of mathematical education in the Russian Federation and introduction of new FSES of general and professional education stochastic knowledge is given the role of the integral component of innovative content of education both general and professional one $[2,3]$. Studying of probabilistic and statistical material has already become compulsory in a school course within the independent substantial and methodical line. According to FSES of main general education studying of subject domain "Mathematics and Information Technologies" has to "provide awareness of mathematics value... as a part of the universal human culture, the universal language of science giving an opportunity to describe and study real processes and phenomena". Studying of mathematics has to promote development of logical thinking, formation of primary skills of mathematical modeling, application of mathematical knowledge in the solution of various tasks and estimation of the received results, development of mathematical intuition.

In the table 1 dynamics of development of "to know-to be able" component is reflected in the structure of stochastic competence in the context of requirements of FSES to the level of training of secondary and high schoolleavers.

In FSES of higher education the component "to own" is added to the structures of the formed competences. From our point of view this component corresponds to acquisition of primary experience of the related activity and, therefore, transition to "indistinct border area" between competencel competency (competence "in operation"). As an example (table 2) we will give the requirements to the structure of the result of teaching promoting formation of professional competence (PC-1) "use of fundamental laws of natural-science 
Table 1

Dynamics of development of components of stochastic competence

\begin{tabular}{|c|c|c|}
\hline $\begin{array}{c}\text { Level } \\
\text { of training }\end{array}$ & To know/to understand & To be able to do \\
\hline $\begin{array}{l}\text { Secondary } \\
\text { school }\end{array}$ & $\begin{array}{l}\text { - probabilistic nature of } \\
\text { many regularities of the world } \\
\text { around; } \\
\quad \text { - examples of the statistical } \\
\text { regularities and conclusions; }\end{array}$ & 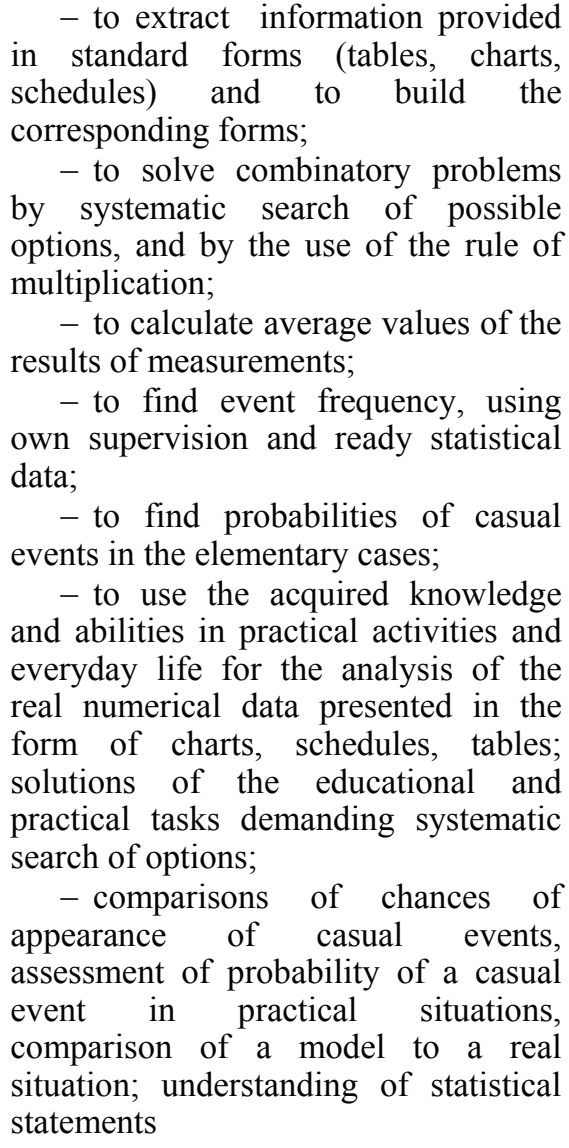 \\
\hline $\begin{array}{l}\text { High } \\
\text { school }\end{array}$ & $\begin{array}{l}\text { - the value of mathematical } \\
\text { science, including the methods } \\
\text { of stochastics, for solving } \\
\text { problems arising in theory and } \\
\text { practice; the value of practice for } \\
\text { the development mathematical } \\
\text { science itself; } \\
\text { - determinated and } \\
\text { probabilistic character of } \\
\text { different processes and } \\
\text { regulations of the world, } \\
\text { knowledge of stochastic data for } \\
\text { predicting phenomena and } \\
\text { processes. }\end{array}$ & $\begin{array}{l}\text { - solve simple combinatory } \\
\text { problems with the use of the simplest } \\
\text { formulas; } \\
\text { - to calculate probability of events } \\
\text { on the basis of calculation of the } \\
\text { number of outcomes and properties of } \\
\text { probability (the simplest cases); } \\
\text { - to analyze massive data, } \\
\text { including the use of the simplest } \\
\text { methods of interpolation and } \\
\text { extrapolation; } \\
\text { - to use acquired knowledge and } \\
\text { skills in practical activity and real life } \\
\text { for: the analysis of information with } \\
\text { statistical character, prediction of the } \\
\text { events on the basis of probabilistic and } \\
\text { statistical methods, the use of acquired } \\
\text { skills in solution of problems of } \\
\text { interrelated disciplines }\end{array}$ \\
\hline
\end{tabular}


disciplines in professional activity, application of methods... modeling, theoretical and experimental studies" (FSES of the direction of teaching of bachelors 270800.62 "Construction and Building"). Here stochastic competence/ competency acts as one of the subsystems integrated into the specified competence PC-1.

In the view of practical orientation of stochastic competence/competency its components "to know", "to be able" and, in particular, "to own/to be able to use", from our point of view are formed in the best way in the course of the use of the so-called case tasks.

2. The concept of case tasks as a processing method of formation of stochastic competence. Existence of this or that competence assumes ability to simultaneous mobilization of knowledge, abilities and ways of behavior in the conditions of concrete activity; as a result of competence formation a student gets an opportunity "to transfer knowledge", to solve problems, new to himself, to master new subject domains, new kinds of activity, etc.

We call methods of formation of competence "technological" if they possess such signs of educational technologies as a focus, scientific validity, a property to be planned and projected, reproducibility and warranty of result.

We understand a case method (a method of cases) as a method of situational analysis. In the course of its application pupils have to understand an essence of problems, propose possible solutions and choose the best one [4]. Cases are based on a real actual material or are approached to a real situation. As a result, creative mastering of practical, professional knowledge and abilities and the development of power of thinking take place. The case method demands abilities to operate by concepts and the facts, building logical schemes

Table 2

\section{Requirements to the structure of the result of teaching}

\begin{tabular}{|c|c|c|}
\hline A student knows: & A student is able to: & A student owns/can use: \\
\hline $\begin{array}{l}\text { fundamental basis } \\
\text { of probability theory and } \\
\text { mathematical statistics: } \\
\text { - concepts of probability } \\
\text { and relative frequency of an } \\
\text { event and basic formulas for } \\
\text { their calculation; } \\
\text { - methods of pointed } \\
\text { and interval estimation } \\
\text { of parameters of distribution; } \\
\text { - concepts and types } \\
\text { of casual processes; } \\
\text { - regression methods } \\
\text { of modeling of experimental } \\
\text { dependences }\end{array}$ & $\begin{array}{l}\text { to use independently } \\
\text { mathematical terms, contained in } \\
\text { special professional literature, to } \\
\text { expand the mathematical } \\
\text { knowledge: } \\
\text { - to solve applied problems } \\
\text { (including, connected with } \\
\text { professional activity) by means of } \\
\text { stochastic methods; } \\
\text { - to use algorithms of check } \\
\text { of statistical hypotheses; } \\
\text { - to build probabilistic and } \\
\text { statistical models of real } \\
\text { situations }\end{array}$ & $\begin{array}{l}\text { primary skills and main } \\
\text { methods of the solution of } \\
\text { mathematical (stochastic) } \\
\text { tasks from all-engineering } \\
\text { and special major } \\
\text { disciplines and methods of } \\
\text { probabilistic modeling: } \\
\text { - to predict in number } \\
\text { the degree of objective } \\
\text { possibility of this or that } \\
\text { phenomenon, nature of } \\
\text { course of this or that } \\
\text { process; } \\
\text { - to interpret statistical } \\
\text { data in terms of variation } \\
\text { ranks and estimate } \\
\text { parameters of distribution; } \\
\text { - to develop regression } \\
\text { models of statistical } \\
\text { dependences }\end{array}$ \\
\hline
\end{tabular}


of a solution, to reason the opinion. The case method integrates in itself other methods of knowledge: analysis, synthesis, description, modeling, a problem method, experiment, classifications, etc., it promotes an optimum combination of theory and practical knowledge, and also abilities relying on the previous experience of practical activities of pupils.

Stochastic case tasks are understood by us as the complex competencebased tasks focused on modeling of the elementary nondeterministic systems.

In the view of a practical orientation they promote increase of motivation to the related mathematical activity. So, for example, for identification of relationships of cause and effect, and in particular, regularities of stochastic character, a student of the main school (and even elementary school) comes, first of all, within his brief personal experience, and the knowledge is acquired by him not for the sake of establishment of communications and the relations between subjects and the phenomena, and in connection with the interest in the corresponding objects of surrounding reality.

In case tasks knowledge and abilities in the field of combination theory, actions over events, calculations of probabilities as directly by definition, and by means of the corresponding theorems, and also the analysis of statistical data with the subsequent forecasting of dependences, etc. can be actualized at the same time. The solution of case tasks makes use, on the one hand, of the experience of mathematical activity which is already saved up by pupils, and on the other hand, promotes its expansion and deepening.

Finally, the solution of case tasks involves the reflection of the related mathematical activity which is shown, in particular, in the analysis of one's own work, development of skills of self-checking, ability to find the reason of difficulty and to find ways of its overcoming, etc.

Thus, according to the structure of stochastic competence /competency described above we can consider a case task as the effective processing method of its formation promoting realization (at the level of educational tasks) the methodological principle of systemacity of researches.

In the following items author's examples of stochastic case tasks are given.

3. The case tasks when studying the stochastic module in the course of mathematics of the main school (partly given in [5]).

Task 1 (schedules, interpolation and extrapolation). Write down air temperature outdoors at 9 p.m. and at 7 a.m. Considering that temperature changes (depending on time which passed from the beginning of supervision) under the linear law (i.e. dependence is represented on the coordinate plane in the form of a straight line), determine approximately temperature, which

a) was at 2 a.m.;

b) was at $11 \mathrm{pm}$, at $1 \mathrm{am}, 3$ a.m. and 5 a.m.

What air temperature can be at 9 a.m. in this case?

Task 2 (table of distribution of frequencies, fashion, scope of selection, selective average). Take from parents the receipt on a rent for the expired calendar period. Write down (on months) the cost of the spent electric power. Then arrange costs as they increase determine the frequency of each of them and make the corresponding table (a variation sequence). Define (if that is available) the cost with the greatest frequency. In what month was the greatest sum paid, and in what month was the smallest sum paid? Why do you think you 
paid most of all and least of all in these months respectively? Define the scope of a variation of cost of the electric power. What is the average monthly cost of the consumed electric power? In what month is the cost most differed from an average one?

Task 3 (relative frequency, statistical probability of an event). In the street with not too heavy traffic observe a transport stream within $2-5$ minutes and write down, how many cars passed by, how many foreign cars were among them, how many private cars and taxis were there. You should find relative frequency of the number

a) of cars in a transport stream;

b) of taxis in a transport stream;

c) of taxis - among cars;

d) of foreign cars - in a transport stream.

What probability can you predict about how soon a taxi will appear the first among the cars passing by?

On the basis of the results of supervision and property of stability of relative frequency define approximate percent of foreign cars in the city transport system.

Task 4 (creation of a number of distribution, numerical characteristics)

Soon it is necessary to pass examinations of the State Final Certification (SFC). What probability do you predict about, how successfully (grade «4» or «5») you will pass examination in Russian? In mathematics? In a foreign language? Make a number of distributions of the number of examinations which you predict you'll pass successfully. Construct a polygon of distribution. What is the most probable number of successfully passed examinations? What is mathematical expectation of the number of successfully passed examinations?

\section{The case tasks when studying the stochastic module in the course of mathematics in high school.}

Task 1 (binomial distribution, number of distribution, mode of distribution, mathematical expectation). Sherlock Holmes investigates a case on a robbery of a bank. The attendant of the bank Mrs. Smith claims that there were three robbers, Ms. Johnson - that two, and Mr. Pete says that ladies doubled or thriced their number because of fear, and that the robber was one. Sherlock Holmes suspects that K, L, N (it doesn't disclose names for secrecy of the investigation, but he is sure that there couldn't be other robbers) could be robbers, each of which participated before, on average, in every third robbery.

Holmes wants to confirm the deductive method with mathematical calculations. What is probability that it was only $\mathrm{K}$, only $\mathrm{L}$, only $\mathrm{N}$; $\mathrm{K}$ and $\mathrm{L}, \mathrm{K}$ and $\mathrm{N}, \mathrm{L}$ and $\mathrm{N}$ or all the three? What is the most probable number of robbers? What is the probability that the bank wasn't robbed at all, and Smith, Johnson and Pete appropriated the money? If a series of similar robberies continues what will the average number of robbers be?

Task 2 (creation of a variation sequence, numerical characteristics of selection). Within twenty days observe and write down ruble exchange rate of a dollar. Arrange options in the range of their increase and make the corresponding variation sequence. Construct polygon distributions. Define a scope of variation of dollar-ruble exchange rates, mode and a median of a variation sequence. Find the average monthly dollar exchange rate. Define its selective mean square deviation. 
5. The case tasks when studying the stochastic module in the course of mathematics of engineering fields of bachelor training. The corresponding tasks can be used in the integrated description of behavior of discrete and continuous random variables, for definition of dot and interval estimates of parameters of theoretical distribution according to empirically obtained data, finding of regression dependences, etc. [6]. We will be limited to the following two examples.

Task 1 (special distributions, density and function of distribution, probability of coincidence of values with the set interval, numerical characteristics). Transport runs regularly with an interval $\tau$ minutes. To determine density and function of distribution of a random variable $t$, that is waiting time of a means of transport by a passenger, in a casual time point coming to a bus stop. What is the probability that waiting time will make no more than $0,25 \tau$ minutes? What is the probability that all five days of a working week a passenger will expect transport no more than $0.25 \tau$ minutes? What is the average time of daily waiting for this means of transport?

Task 2 (linear and nonlinear regressions, forecasting of values). Electricity consumption indicators (in kilowatts) $y_{j}$ depending on time (in hours) continuous operation of the device $x_{j}$ are recorded. Investigate possible dependence of size $y_{j}$ from $x_{j}$, having used for this purpose the sampling equations a) linear, b) parabolic, c) logarithmic regression according to the following data of measurements:

$\begin{array}{ccccccc}y_{j}: & 5,2 & 6,3 & 7,1 & 8,5 & 9,2 & 10,0 \\ x_{j}: & 1 & 2 & 3 & 4 & 5 & 6\end{array}$

Define the most preferable model of dependence, having used calculation of residual dispersion for each model. On the chosen model predict the size of the consumed electric power in 15 and 20 hours of continuous operation of the device.

\section{References}

1. Селютин, В. Д. Научные основы методической готовности учителя обучению школьников стохастике : монография / В. Д. Селютин. - Орел: ОГУ, 2002. $200 \mathrm{c}$.

2. Концепция развития российского математического образования [Электронный pecypc] // Math.ru : сайт. - Режим доступа : www.math.ru/conc/vers/conc3003.html (дата обращения: 21.06.2014).

3. Аверина, И. В. Уровневая модель системы мероприятий по реализации концепции развития российского математического образования [Электронный pecypc] / И. В. Аверина, А. Д. Нахман //Актуальные инновационные исследования: наука и практика. - 2014. - № 1. - Режим доступа : http://www.actualresearch.ru.pdf (дата обращения: 12.04.2015).

4. Гумметова, А. Ю. Кейс-метод как современная технология личностно-ориентированного обучения [Электронный ресурс] / А. Ю. Гумметова, Е. В. Ступина // Учительский портал. - Режим доступа : http://www.uchportal.ru/publ/15-1-0-507 (дата обращения: 12.04.2015).

5. Зайцев, В. Л. Элементы математической логики и стохастики : учеб.-метод. пособие / В. Л. Зайцев, С. А. Каратеева, А. Д. Нахман. - Тамбов: ТОПКРИО, 2008. $46 \mathrm{c}$. 
6. Куликов, Г. М. Элементы прикладной математики: учебное пособие / Г. М. Куликов, А. Д. Нахман, С. В. Плотникова. - Тамбов : Изд-во Тамб. гос. техн. ун-та, 2008. -160 с.

\section{References}

1. Selyutin V.D. Nauchnye osnovy metodicheskoi gotovnosti uchitelya obucheniyu shkol'nikov stokhastike (Scientific bases of methodical readiness of the teacher to training of school students in stochastics), Oryol: OGU, 2002, $200 \mathrm{p}$.

2. www.math.ru/conc/vers/conc-3003.html (accessed 21 June 2014).

3. Averina I.V., Nakhman A.D. Level model of system of actions for implementation of the concept of development of the Russian mathematical education. Electronic scientific publication "Actual innovative researches: science and practice", 2014, № 1 .

4. Gummetova A.Y., Stupina E.V., available at: http://www.uchportal.ru/publ/ 15-1-0-507 (accessed 12 April 2015).

5. Sayzev V.L., Karateeva S.A., Nakhman A.D. Elementy matematicheskoi logiki $i$ stokhastiki (Elements of mathematical logic and stochastics), Tambov: Tambovskii institut povysheniya kvalifikatsii rabotnikov obrazovaniya, 2008, $46 \mathrm{p}$.

6. Kulikov G.M., Nakhman A.D., Plotnikova S.V. Elementy prikladnoi matematiki (Elements of applied mathematics), Tambov: Publishing house of Tambov State technical university, 2008, $160 \mathrm{p}$.

\section{Кейс-задания как средство формирования стохастической компетенции}

\section{А. Д. Нахман, И. Ю. Иванова, Т. В. Селянская}

ФГБОУ ВПО «Тамбовский государственный технический университет», ТОГОАУ ДПО «Тамбовский институт повышения квалификачии работников образования», г. Тамбов

Ключевые слова: кейс-задания; стохастическая компетенция; технологические приемы.

Аннотация: Проанализированы структура стохастической компетенции учащихся и условия ее формирования. Предложена концепция кейс-заданий как компонент технологического процесса формирования стохастической компетенции. Сконструирована серия оригинальных кейс-заданий.

() А. Д. Нахман, И. Ю. Иванова, Т. В. Селянская, 2015 